Arboriculture \& Urban Forestry 2015. 41(2): 75-87

\title{
Nursery Planting Depth, Mulch Application, and Root Pruning at Landscape Planting Affect Tree Health and Anchorage
}

\author{
Edward F. Gilman, Maria Paz, and Chris Harchick
}

\begin{abstract}
Influence of root collar depth in a nursery root ball and potential root remediation when planting into the landscape are subject of increasing research. Mulch placement on root ball surface at planting has also been called into question recently. Trees planted deeply in nursery containers required $\geq 41 \%$ more time to remove substrate and roots growing over the root collar at planting than trees planted shallowly. Circling roots on trees planted from $170 \mathrm{~L}$ containers persisted for five growing seasons after planting into the landscape unless remediated by pruning at planting. Root remediation improved Ulmus and Acer root systems by dramatically reducing percent trunk circled with roots without influencing post-planting xylem potential, crown growth, or anchorage during the first five years after landscape planting. Mulch placed on the root ball surface caused more re-growth of circling roots on Acer-but not Ulmus-following root remediation. Bending stress to tilt trunks was most correlated with cross-sectional area of leeward and straight roots on Ulmus or windward and straight roots on Acer. The initial increase with time in bending stress required to tilt trunks after planting followed by a drop in bending stress suggests that trees planted from nursery containers could be more susceptible to uprooting in a wind storm as they became established beyond three or four years.

Key Words. Acer; Bending Stress; Circling Roots; Elm; Maple; Root Ball; Root Collar; Root Flare; Root Remediation; Root Systems; Stem-Girdling Roots; Trunk Damage; Trunk Flare; Ulmus.
\end{abstract}

In recognition of the potential problems of planting the root collar too deeply in the root ball, the ANSI Z60 American nursery stock standard (Anonymous 2004) does not consider soil above the root collar as part of root ball depth. There is good evidence for reduced as well as for equal growth rate in the nursery when the root collar is installed deeply in container substrate depending on study location, planting depth, and taxa (Browne and Tilt 1992; Fare 2005; Gilbin et al. 2005; Byran et al. 2010; Harris and Day 2010). Gilman and Harchick (2008) and Harris and Day (2010) showed that certain taxa generate adventitious roots from the buried stem in the nursery container or after landscape planting from small containers. They agree that adventitious roots may function to aid in establishment of certain deeply planted young trees, although some taxa do not appear to have the capacity to grow new roots from the buried stem. There is growing evidence that planting deeply when installing certain taxa into a landscape reduces survival or growth rates (Arnold et al. 2007). However, Bryan et al. (2010) and Harris and Day (2010) showed that height and trunk diameter growth after landscape planting was little affected by root collar depth in nursery containers. There is little published on the impact of root collar depth in a container root ball on root attributes and anchorage in the landscape.

Removing defects by pruning roots when trees of at least nine taxa were shifted to the next larger size dramatically reduced number of trees grading as culls (Anonymous 1998) in nursery containers (Harris et al. 1971a; Harris et al. 1971b; Gilman et al. 2009; Gilman et al. 2010c). Growing in certain container types can also improve quality by reducing root deflection (Gilman et al. 2010a; Gilman and Paz 2014). Less is known about the influence of root remediation (removal of roots growing over the root collar) at landscape planting on growth, root morphology, health, and anchorage. Harris 
and Day (2010) showed little impact on postplanting growth. Two studies found a significant but small increase in anchorage when root ball sides were shaved of peripheral roots at planting (Gilman and Wiese 2012; Gilman 2013). Experience with one species (Acer platanoides L.) shows that remediation a decade or more after planting is much more difficult and may be ineffective (Tate 1980; Watson and Clark 1993). Earlier remediation may require fewer inputs and be more effective.

Although mulch applied to the soil beyond the root ball appears to moderate soil temperature and moisture measured outside the root ball (Scharenbroch 2009), there are a limited number of instances where mulch has been shown to enhance establishment of landscape-sized trees. No studies showed increased survival rates resulting from applications of mulch around the root ball; however, at least four showed a slight increase in growth for some of the species tested (Litzow and Pellett 1983; Smith et al. 2000; Montague et al. 2007; Arnold and McDonald 2009). In most studies, trees planted in mulched landscape soil in different climates responded identically to those surrounded by bare soil (Kraus 1998; Downer and Hodel 2001; Gilman and Grabosky 2004; Bryan et al. 2008; Ferrini et al. 2008; Singer and Martin 2009). Mulch placed on the root ball surface or on the surrounding soil has been associated with reduced survival (Arnold et al. 2005; Singer and Martin2009), increased stress (Gilman and Grabosky 2004), or reduced post-planting tree growth (Hensley et al. 1988; Hild and Morgan 1993); these symptoms typically appeared soon after planting.

With questionable benefits of mulch application over the root-ball surface, and limited data on the influence of planting depth in nursery containers and root remediation at planting, this study was designed to test the interactions of these three factors for two commonly planted taxa in temperate urban landscapes. Influence on physiological stress symptoms, crown and root growth, and anchorage was the focus of this investigation.

\section{MATERIALS AND METHODS}

\section{Trees and Treatments}

Rooted cuttings with stem tips originally stuck approximately $4 \mathrm{~cm}$ deep into propagation containers $(5.1 \mathrm{~cm}$ diameter and $13 \mathrm{~cm}$ tall ribbed containers,
38 Groovetube, Growing Systems, Inc., Milwaukee, Wisconsin, U.S.) were planted into $11.4 \mathrm{~L}$ (\#3) Air-Pots $(29 \mathrm{~cm}$ tall $\times 26 \mathrm{~cm}$ top diameter, Superoots $^{\circledast}$ Air-Pot $^{\text {th }}$ black plastic (Caledonian Tree Company, Ltd., Scotland) either with the point where the topmost root emerged from the stem (i.e., the root collar) $13 \mathrm{~mm}$ below substrate surface or $64 \mathrm{~mm}$ below the surface. Excess substrate was removed above the topmost root just prior to planting all trees into $11.4 \mathrm{~L}$ containers. Ten months later, trees planted $13 \mathrm{~mm}$ deep were shifted to $57 \mathrm{~L}$ (\#15) Air-Pots $(33 \mathrm{~cm}$ tall $\times 46 \mathrm{~cm}$ top diameter) even with the surface; trees planted $64 \mathrm{~mm}$ deep were planted another $64 \mathrm{~mm}$ deep. The result was two planting depths, shallow (13 $\mathrm{mm})$ and deep (128 $\mathrm{mm}$ ) into $57 \mathrm{~L}$ containers. After 14 months, all trees were shifted into smoothsided $170 \mathrm{~L}(\# 45)$ containers $(47 \mathrm{~cm}$ tall and 75 $\mathrm{cm}$ top diameter, Nursery Supplies Inc., Fairless Hills, Pennsylvania, U.S.) even with the substrate surface. Eighteen months later (February 2008), 40 elms (Ulmus parvifolia Jacq.) and 40 maples (Acer rubrum L. 'Florida Flame') selected for uniformity in $170 \mathrm{~L}$ smooth-sided containers were planted in the landscape a few hundred meters away. No root pruning was performed in the nursery.

Substrate in all containers was composed of 60 pine bark: 30 New Florida peat: 10 sand by volume (Florida Potting Soil, Inc., Orlando, Florida, U.S.). New Florida peat is a compost of Florida peat and hardwood fine particles (Florida Potting Soil, Inc.). Irrigation and fertilizer commonly used in the region to foster rapid growth were applied while trees were in containers. Trees were irrigated two or three times daily during the growing season and once daily at other times, except in wet and cool weather. Tree crowns were pruned twice annually to meet Florida Grades and Standards for Nursery Plants (Anonymous 1998) with one dominant central leader and the first permanent branches beginning $1.4 \mathrm{~m}$ from ground. Trees were arranged in the nursery in plots described in the literature (Gilman et al. 2010b).

Soil at the landscape planting site was a Millhopper fine sand (loamy, siliceous, hyperthermic Grossarenic Paleudults) with less than $2 \%$ organic matter at University of Florida Great Southern Tree Conference demonstration site in Alachua County, Florida, U.S. (USDA hardiness zone $8 \mathrm{~b}$ ). 
Before planting, 10 trees of each nursery planting depth and species $(10 \times 2 \times 2=40$ trees total $)$ were air excavated as deep as possible (approximately $10 \mathrm{~cm}$ ) to expose the point where the structural roots emerged from the trunk (root collar). Roots positioned over the collar (either crossing over structural roots, tangent to, or circling the trunk) were removed with hand pruners to the edge of the $170 \mathrm{~L}$ root ball. Roots were cut by the same person with a hand saw or pruners before they deflectedwhere possible-in an attempt to encourage new roots to grow from the cuts radially away from the trunk. This was not always possible because some cut roots had grown upward within the root ball, resulting in the cut surface facing the sky. Moreover, roots growing against the trunk were difficult to cut at the ideal position-however they were cut-because they were partially embedded in the trunk. Roots that were deflected by the $11.4 \mathrm{~L}, 57 \mathrm{~L}$, and $170 \mathrm{~L}$ containers but not growing over the collar were cut just proximal to the deflected portion of the root. A second air excavation and root pruning was required to remove the remaining substrate and roots over the collar and main structural roots; this was conducted immediately following the first. Total time to remove roots (root remediation) on each root ball was recorded. The remaining 20 trees of both taxa (40 trees total) were not root remediated when planting into the landscape.

Holes 10 to $15 \mathrm{~cm}$ wider than root balls were dug with straight sides and flat bottoms and adjusted so the top of the root ball was about $5 \mathrm{~cm}$ higher than the surrounding landscape soil surface. One person tamped the bottom of holes by foot to standardize settling. Once the root ball was placed in the planting hole a $15 \mathrm{~cm}$ wide volume of undisturbed soil at the edge of hole was loosened and pushed into the hole. The rest of the void around the root ball was filled with soil removed from the planting hole. Water was added to settle backfill soil, and soil was packed firmly by foot to standardize compaction. No berm or water ring was constructed around the root balls. Weeds were controlled with periodic (three to four) annual applications of Glyphosate (isopropylamine salt, 41\%) down each row. Trees were planted on $2.4 \mathrm{~m}$ centers in rows $3 \mathrm{~m}$ apart and stabilized with two pieces of non-treated lumber $(3.8 \mathrm{~cm} \times 5.3 \mathrm{~cm} \times 50 \mathrm{~cm}$ long, Terra Toggle, root ball stabilization system, Accuplastics Inc.,
Brooksville, Florida, U.S.) secured to earth anchors in June 2008; they were removed June 2009.

Wood chip mulch from local line-clearance operations, typically consisting of leaves, twigs, and chipped wood, was applied $12 \mathrm{~cm}$ deep before settling in a $1.8 \mathrm{~m}$ wide strip down all rows. Mulch was withheld from the top of the root ball on half the trees of each taxa that were root remediated and from half the trees that were not (40 trees total); remaining trees (40 trees) were mulched to within $5 \mathrm{~cm}$ of the trunk resulting in $7 \mathrm{~cm}$ over the root ball. Root collar and roots exposed by the root remediation treatment were left exposed to the atmosphere; they were covered by $7 \mathrm{~cm}$ of mulch in the mulch to the trunk treatment. Mulch was not managed in any way other than a reapplication in April 2010 to original dimensions.

Trees were irrigated with $20 \mathrm{~L}$ applied over the root ball three times weekly until November 3, 2010, when irrigation ceased. One Roberts SpotSpitters (Roberts Irrigation Products, Inc., San Marcos, Idaho, U.S.) positioned at the edge of the root ball directed water toward the trunk. Trees were fertilized with $400 \mathrm{~g}$ of 16-4-8 applied to the root ball surface March and June 2008 and 2009, and with 400 g 20-0-8 March and May 2010, and March 2011. Trees were not pruned after planting into the landscape other than to remove small diameter drooping branches for mower clearance.

\section{Evaluating Growth and Health}

Trunk diameter $30 \mathrm{~cm}$ above ground was measured at planting (February 2008) and every October thereafter through 2012. Tree height was measured at planting and October 2008 and 2009. Percentage of trunk circumference with visibly sunken and dead bark, evaluated by presence of live woundwood on either side of the dead bark, was measured in March 2009 on the lower $50 \mathrm{~cm}$ of the trunk using a diameter tape.

Elm trees were dug from the ground (July 2013) with a $122 \mathrm{~cm}$ diameter (top of root ball) tree spade, and maples were dug with a hand shovel, to the same dimensions, and lifted with a tractor; soil was washed from the roots. Diameter of all roots $>15 \mathrm{~mm}$ at the largest point and that perpendicular to it was measured with a micro-caliper $10 \mathrm{~cm}$ beyond the edge of the original $170 \mathrm{~L}$ container root ball down to the bottom of the original container in a pie-shaped volume representing the 
northern and southern $25 \%$ quadrants. Root crosssectional area (CSA) was calculated from the mean diameter. Other measurements included the following: whether the first $10 \mathrm{~cm}$ of the root segment growing into landscape soil from the original $170 \mathrm{~L}$ container root ball edge was deflected $<60$ degrees in either azimuth direction relative to the azimuth of its parent root inside the root ball (straight roots); whether the same root segment descended or ascended at $<$ or $>45$ degrees relative to the soil surface; distance between soil surface and top of root (root depth) measured $10 \mathrm{~cm}$ from $170 \mathrm{~L}$ root ball edge; diameter (mean of largest diameter and that perpendicular to it) of the largest root circling at the position of the $170 \mathrm{~L}$ container edge; and percentage of total trunk circumference circled with roots $>5 \mathrm{~mm}$ diameter at any position.

Stem xylem water potential was measured one block at a time after prolonged, normal, hot, dry, and sunny weather 15 months after planting (May 6 and 8, 2009). Irrigation was withheld during this period. Xylem potential was measured 12:00 to 14:00 hour with a pressure chamber (Soil Moisture Inc., Santa Barbara, California, U.S.) on all 80 trees. Terminal portions $(10 \mathrm{~cm}$ long) of current year twigs growing in full sun were cut with a hand pruner about half way up the southern side of the crown and were immediately placed in the pressure chamber. Pressure was increased in the air-tight chamber at a constant rate of 30 seconds per MPa. Pressure was recorded when cut stem surface became uniformly wet.

\section{Evaluating Anchorage}

All 80 trees were pulled to the south with a steel cable and electric winch (Model 40764; Chicago Electric Power Tools, Inc., Camarillo, California, U.S.) attached to a tractor in March 2011, February 2012, and May 2013 to evaluate lateral tree stability (anchorage). There was no prevailing wind direction at the site. An electronic inclinometer (model 3DM-GX1, Microstrain Inc., Vermont, U.S.) was secured with brass screws to the trunk base $15 \mathrm{~cm}$ from soil surface, immediately above the swollen flare at trunk base. A $3,629 \mathrm{~kg}$ capacity load cell (SSM-AF-8000; Interface Inc., Scottsdale, Arizona, U.S.) was placed in-line with the steel pulling cable attached to the trunk about $1 \mathrm{~m}$ from ground.
The cable was pulled so it remained parallel to the ground at a rate of $2 \mathrm{~cm} \cdot \mathrm{s}^{-1}$ until trunk base tilted five degrees (in 2011 and 2012) and to 20 degrees (2013) from the vertical start position. Trees were held for 60 seconds at five or 20 degrees tilt; when the trunk was released, final trunk tilt was recorded as rest angle. During pulling tests, load cell and inclinometer measurements were sampled at $20 \mathrm{~Hz}$ using a 16-bit data acquisition system (National Instruments Corporation, Austin, Texas, U.S.) and displayed and archived in realtime on a laptop running LabView software (v: 7.0; National Instruments, Austin, Texas, U.S.). The trunk bending stress was calculated as: (pulling force $\times$ distance from pulling point to inclinometer $\times$ trunk radius at inclinometer calculated from a diameter tape measurement $) \div\left(0.25 \pi \times\right.$ trunk radius $\left.{ }^{4}\right)$. Trunk radius was calculated by halving diameter measured with a diameter tape just before each pull.

\section{Experimental Design and Statistical Analysis}

Experimental design was a randomized complete block design for each taxa separately with eight treatment combinations assigned at random to five blocks for a total of 40 trees/taxa. Eight treatments resulted from the two planting depths in nursery containers $x$ two root remediation at planting treatments $\times$ two mulch treatments after planting. Taxa were planted in adjacent plots and analyzed independently. Repeated measures three-way ANOVA was used to analyze differences between levels of main effects and interactions. Means for main effects were separated with Tukey's multiple range test; those for interactions with LSD. Time to remove substrate and roots was compared with a t-test. Pearson's Correlation Coefficients were calculated between root measurements and bending stress. Significance was assessed at $P<0.05$ unless indicated.

\section{RESULTS}

\section{Shoot and Root Response}

None of the three factors tested impacted stem xylem potential or tree height growth after planting for either taxa (data not shown). Trees of both taxa planted deeply in the nursery container 
required more time to remove substrate and roots growing over the root collar at planting than trees at the shallower nursery depth (Table 1). There was no impact of nursery planting depth on trunk diameter growth of either taxa in any year after landscape planting (data not shown), and there were only isolated impacts on trunk diameter growth from root remediation at planting. For example, trunk diameter increase was slightly $(P=0.02)$ less in the first year after planting on root-remediated elms $(6 \mathrm{~mm})$ than on non-pruned trees $(9 \mathrm{~mm})$; diameter increase was not impacted by root remediation in any subsequent year for either taxa (data not shown). Withholding mulch from root ball surface, regardless of root remediation or nursery planting depth, in the third (2010) through fifth (2012) year after planting resulted in a trunk diameter increase for elms (Figure 1) but not maples.

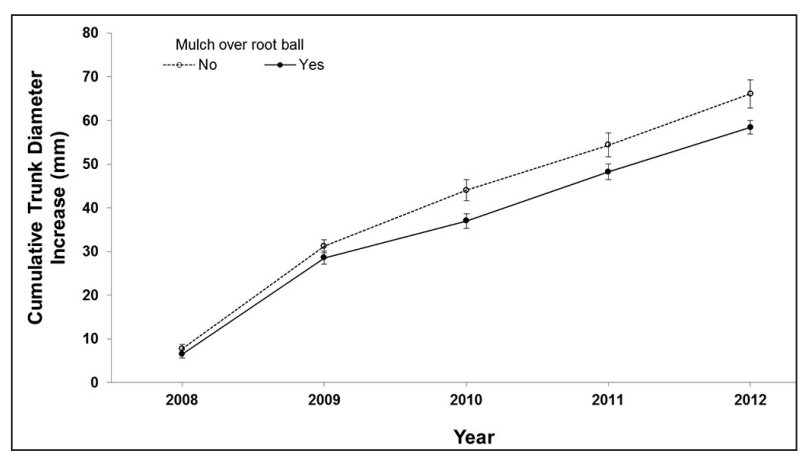

Figure 1. Effect of mulch over root ball on cumulative elm trunk diameter increase (measured in October of indicated year) in the first five years after landscape planting $(P<$ 0.04 ); vertical bars indicate SE. Note: All trees in both treatments received mulch from the edge of the root ball outward starting at planting Feb 2008; mulch did not impact maples $(P>0.33)$.
Maples installed from the shallow nursery planting depth had more CSA of straight roots $\left(4,340\right.$ versus $\left.3,614 \mathrm{~mm}^{2}, P=0.04\right)$ and more (166 versus $195 \mathrm{~mm}, P=0.02$ ) shallow roots ( $>5$ $\mathrm{mm}$ diameter) five years after landscape planting than those planted deeply (respectively) in the nursery container (means averaged across root remediation and mulch treatments - interactions insignificant, $P>0.05$ ). Total root CSA (to 68 $\mathrm{cm}^{2}$ from $56 \mathrm{~cm}^{2}, P=0.03$ ) and CSA of straight roots (to $46 \mathrm{~cm}^{2}$ from $38 \mathrm{~cm}^{2}, P=0.006$ ) also increased on root remediated compared to nonremediated maples (respectively), but not elms. Root remediation dramatically reduced percent trunk circled with roots ( $>5 \mathrm{~mm}$ diameter) five years after planting for both taxa planted deeply in containers $(P=0.01$, Table 2$)$ and for maples planted shallowly. Root remediation reduced elm root depth five years after planting when nursery planting depth was shallow but not when deep. The CSA of the largest circling root on maples planted shallowly was less than for trees planted deeply in containers (5 versus $15 \mathrm{~cm}^{2}$, Table 2), but only for root-remediated trees. Straight roots were closer to the soil surface for maples planted shallowly than deeply in containers; same for maples root remediated at planting than not. The reduction in root circling on maples from root remediation was most pronounced on trees without mulch on the root ball (7\% of trunk circumference, Table 3). Straight root CSA was smallest $\left(22 \mathrm{~cm}^{2}\right)$ on trees not root remediated at planting and without mulch on the root ball. Mean depth of straight roots $(22 \mathrm{~cm})$ was greatest for maples not remediated and with mulch on the root ball.

Table 1. Effect of nursery planting depth on time required for root remediation at planting (air excavate top of root ball plus prune to remove roots growing over the root collar).

\begin{tabular}{|c|c|c|c|}
\hline $\begin{array}{l}\text { Nursery planting } \\
\text { depth }^{z}\end{array}$ & $\begin{array}{l}\text { Air excavation time } \\
\text { (seconds) }\end{array}$ & $\begin{array}{l}\text { Elm } \\
\text { Root pruning time } \\
\text { (seconds) }\end{array}$ & $\begin{array}{l}\text { Total (excavation + prune) time } \\
\text { (seconds) }\end{array}$ \\
\hline Shallow & $70 \mathrm{~b}^{y}$ & $185 \mathrm{~b}$ & $255 \mathrm{~b}$ \\
\hline Deep & $102 \mathrm{a}$ & $328 \mathrm{a}$ & $430 \mathrm{a}$ \\
\hline $\begin{array}{l}\text { Nursery planting } \\
\text { depth }\end{array}$ & $\begin{array}{l}\text { Air excavation time } \\
\text { (seconds) }\end{array}$ & $\begin{array}{l}\text { Maple } \\
\text { Root pruning time } \\
\text { (seconds) }\end{array}$ & $\begin{array}{l}\text { Total (excavation + prune) time } \\
\text { (seconds) }\end{array}$ \\
\hline Shallow & $98 b^{z}$ & $380 \mathrm{~b}$ & $478 \mathrm{~b}$ \\
\hline Deep & $153 \mathrm{a}$ & $756 a$ & $909 \mathrm{a}$ \\
\hline
\end{tabular}


Table 2. Effect of nursery planting depth and root remediation on root attributes five years later after planting into the landscape.

\begin{tabular}{|c|c|c|c|c|c|c|}
\hline $\begin{array}{l}\text { Nursery planting } \\
\text { depth }^{z}\end{array}$ & $\begin{array}{l}\text { Root remediation } \\
\text { at planting }\end{array}$ & $\begin{array}{l}\% \text { trunk circled } \\
\text { at planting }\end{array}$ & $\begin{array}{l}\text { Elm } \\
\text { \% trunk circled } 5 \text { years } \\
\text { after planting }\end{array}$ & $\begin{array}{l}\text { Root depth-north } \\
(\mathrm{cm})\end{array}$ & $\begin{array}{l}\text { Depth of straightw } \\
\text { roots-north }(\mathrm{cm})\end{array}$ & $\begin{array}{l}\text { Depth of descending } \\
\text { roots-north }(\mathrm{cm})\end{array}$ \\
\hline \multirow[t]{2}{*}{ Shallow } & Yes & $36 b^{u}$ & $3 \mathrm{~b}$ & $14 \mathrm{~b}$ & $10 \mathrm{~b}$ & $17 \mathrm{~b}$ \\
\hline & No & $36 \mathrm{~b}$ & $22 \mathrm{~b}$ & $26 \mathrm{a}$ & $22 \mathrm{a}$ & $30 \mathrm{a}$ \\
\hline \multirow[t]{2}{*}{ Deep } & Yes & $68 \mathrm{a}$ & $1 \mathrm{~b}$ & $20 \mathrm{ab}$ & $21 \mathrm{a}$ & $22 \mathrm{ab}$ \\
\hline & No & $68 \mathrm{a}$ & $55 \mathrm{a}$ & $20 \mathrm{ab}$ & $20 \mathrm{a}$ & $22 \mathrm{ab}$ \\
\hline $\begin{array}{l}\text { Nursery planting } \\
\text { depth }^{z}\end{array}$ & $\begin{array}{l}\text { Root remediation at } \\
\text { planting }\end{array}$ & $\begin{array}{l}\% \text { trunk circled at } \\
\text { planting }^{\text {xy }}\end{array}$ & $\begin{array}{l}\text { Maple } \\
\% \text { trunk circled } 5 \text { years } \\
\text { after planting }\end{array}$ & $\begin{array}{l}\text { CSA largest circling } \\
\text { root-north }\left(\mathrm{cm}^{2}\right)\end{array}$ & $\begin{array}{l}\text { Depth of straight }{ }^{\mathrm{w}} \\
\text { roots }(\mathrm{cm})\end{array}$ & \\
\hline \multirow[t]{2}{*}{ Shallow } & Yes & $41 \mathrm{~b}^{\mathrm{s}}$ & $9 c$ & $5 \mathrm{~b}$ & $13 \mathrm{~b}$ & \\
\hline & No & $41 \mathrm{~b}$ & $66 \mathrm{~b}$ & $11 \mathrm{ab}$ & $16 \mathrm{~b}$ & \\
\hline \multirow[t]{2}{*}{ Deep } & Yes & $77 \mathrm{a}$ & $22 c$ & $15 \mathrm{a}$ & $14 \mathrm{~b}$ & \\
\hline & No & $77 \mathrm{a}$ & $85 \mathrm{a}$ & $8 \mathrm{ab}$ & $22 \mathrm{a}$ & \\
\hline
\end{tabular}

${ }^{\mathrm{z}}$ Shallow $=$ topmost root $13 \mathrm{~mm}$ deep into $11.4 \mathrm{~L}(\# 3)$ and even with substrate surface into $57 \mathrm{~L}$ (\#15) and 170 L (\#45) container; deep = topmost root $64 \mathrm{~mm}$ deep into 11.4 and $57 \mathrm{~L}$ containers (128 $\mathrm{mm}$ deep total), and even into $170 \mathrm{~L}$ container.

${ }^{y}$ Data presented in Gilman et al. 2010b; means for root pruning yes and no are identical because roots were not pruned in that study.

x Percentage of trunk circumference circled with roots $>5 \mathrm{~mm}$ diameter.

${ }^{w}$ Straight $=$ root segment just beyond the root ball was oriented $<60$ degrees in either compass direction compared to azimuth of parent root inside root ball; depth measured $10 \mathrm{~cm}$ outside root ball.

${ }^{v}$ Descending $=$ growing down $<45$ degrees in relation to landscape soil surface on north side of tree.

${ }^{u}$ Means for elm followed by a different letter within columns are statistically different at $P=0.05,0.01,0.006,0.003$, and 0.02 , left to right; $\mathrm{n}=10$, averaged over mulch treatment due to insignificant interaction $(P>0.05)$.

${ }^{t}$ Diameter of largest root circling the north half of the tree at the position of the $170 \mathrm{~L}$ root ball; there was no effect on circling roots on south side.

${ }^{s}$ Means for maple followed by a different letter within columns are statistically different at $P=0.01,0.001,0.008$, and 0.04 , left to right; $\mathrm{n}=10$, averaged over mulch treatment because of insignificant interaction $(P>0.05)$.

Table 3. Effect of root remediation when landscape planting and mulch application over the root ball on maple root attributes five years later.

\begin{tabular}{|c|c|c|c|c|}
\hline $\begin{array}{l}\text { Root remediation } \\
\text { at planting }\end{array}$ & $\begin{array}{l}\text { Mulch } 7 \mathrm{~cm} \text { deep } \\
\text { over root ball }\end{array}$ & $\begin{array}{l}\% \text { trunk circled } 5 \text { years } \\
\text { after plantingz }\end{array}$ & $\begin{array}{l}\text { Total straight }{ }^{\mathrm{y}} \text { root } \\
\text { CSA }\left(\mathrm{cm}^{2}\right)\end{array}$ & $\begin{array}{l}\text { Depth of straight }{ }^{y} \\
\text { roots }(\mathrm{cm})\end{array}$ \\
\hline \multirow[t]{2}{*}{ Yes } & Yes & $25 b^{x}$ & $45 \mathrm{a}$ & $13 \mathrm{~b}$ \\
\hline & No & $7 c$ & $59 a$ & $14 \mathrm{~b}$ \\
\hline \multirow[t]{2}{*}{ No } & Yes & $69 \mathrm{a}$ & $45 \mathrm{a}$ & $22 \mathrm{a}$ \\
\hline & No & $83 \mathrm{a}$ & $22 \mathrm{~b}$ & $15 \mathrm{~b}$ \\
\hline
\end{tabular}

${ }^{\mathrm{z}}$ Percentage of trunk circumference circled with roots $>5 \mathrm{~mm}$ diameter.

y Straight = root segment just beyond the root ball oriented $<60$ degrees in either compass direction compared to azimuth of parent root inside root ball; depth measured $10 \mathrm{~cm}$ outside root ball.

${ }^{\mathrm{x}}$ Means followed by a different letter within columns are statistically different at $P=0.002,0.006$, and 0.01 left to right, respectively; $\mathrm{n}=10$, averaged over nursery

planting depth due to insignificant interaction with nursery planting depth $(P>0.18)$.

Table 4. Effect of root remediation at planting, mulch, and nursery planting depth on maplez trunk bark death evaluated 15 months after planting, and root depth five years after planting into landscape soil.

\begin{tabular}{|c|c|c|c|}
\hline $\begin{array}{l}\text { Mulch } 7 \mathrm{~cm} \text { deep } \\
\text { over root ball }\end{array}$ & $\begin{array}{l}\text { Root remediation } \\
\text { at planting }\end{array}$ & $\begin{array}{l}\% \text { circumference of trunk } \\
\text { with bark dead }\end{array}$ & $\begin{array}{l}\text { Depth of straight }{ }^{y} \\
\text { roots }(\mathrm{cm})\end{array}$ \\
\hline \multirow[t]{2}{*}{ Yes } & Yes & $52 \mathrm{a}^{\mathrm{x}}$ & $13 \mathrm{~b}$ \\
\hline & No & $19 c$ & $22 \mathrm{a}$ \\
\hline \multirow[t]{2}{*}{ No } & Yes & $41 b$ & $14 \mathrm{~b}$ \\
\hline & No & $38 \mathrm{~b}$ & $15 \mathrm{~b}$ \\
\hline $\begin{array}{l}\text { Nursery planting } \\
\text { depth }^{w}\end{array}$ & $\begin{array}{l}\text { Root remediation } \\
\text { at planting }\end{array}$ & $\begin{array}{l}\% \text { circumference of trunk } \\
\text { with bark dead }\end{array}$ & \\
\hline \multirow[t]{2}{*}{ Shallow } & Yes & $46 \mathrm{a}^{\mathrm{x}}$ & \\
\hline & No & $45 \mathrm{a}$ & \\
\hline \multirow[t]{2}{*}{ Deep } & Yes & $41 \mathrm{a}$ & \\
\hline & No & $18 \mathrm{~b}$ & \\
\hline
\end{tabular}

${ }^{\mathrm{z}}$ Elms experienced no trunk bark death.

y Straight $=$ root segment just beyond the root ball oriented $<60$ degrees in either compass direction compared to azimuth of parent root inside root ball; depth measured $10 \mathrm{~cm}$ outside root ball.

${ }^{x}$ Means followed by a different letter within columns are statistically different at $P<0.001 ; \mathrm{n}=10$, insignificant three-way interaction $(P>0.87)$.

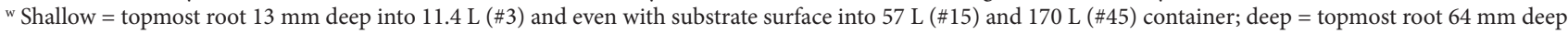
into 11.4 and $57 \mathrm{~L}$ containers (128 $\mathrm{mm}$ deep total), and even into $170 \mathrm{~L}$ container. 
Unlike maples, elms experienced no visible trunk bark death from any factor tested (data not shown). Applying mulch to the root ball surface without remediating roots when planting maples resulted in the least amount of bark death; by contrast, remediation combined with a mulched root ball resulted in the greatest bark death (Table 4). Trunks on remediated maples were more damaged than on those not remediated, but only when mulch was on the root ball. Maples planted deeply into nursery containers without remediating roots resulted in $18 \%$ of the trunk bark circumference dead 15 months after landscape planting (Table 4); all other combinations of nursery planting depth and root remediation at planting resulted in a significant increase in maple bark death.

The diameter of the largest circling root on maples (not elms) increased with mulch on the root ball compared to no mulch (36 versus $28 \mathrm{~mm}$ diameter, $P=0.01$, respectively). Mulch on the root ball increased root depth (mean depth $=22$ $\mathrm{cm})$ compared to no mulch $(17 \mathrm{~cm})$ when maple trees were planted deeply in the nursery container but not when planted shallowly (data not shown). Mulch over elm root balls reduced CSA of roots measured just outside the original $170 \mathrm{~L}$ root ball, but only on north side of the tree, compared to no mulch (14 versus $26 \mathrm{~cm}^{2}, P=0.01$, respectively).

\section{Anchorage}

There were no audible popping noises indicative of root failure during winching to five degrees in years three and four. Root popping noises were apparent the fifth year when pulling to 20 degrees. Bending stress required to tilt elm trunks three to five degrees at three (Figure 2A) and four (not shown) years after planting, and up to 20 degrees at five years after planting (Figure 2B), was greater for trees planted deeply than shallowly in nursery containers. Mulch placement had no influence on bending stress in the third or fourth year after planting (data not shown); however, by the fifth year after planting, elms with mulch placed on the root ball surface required more bending stress to tilt trunks to 5,10 , and 15 degrees, than trees without mulch on the root ball (Table 5). Presence of mulch over the root ball interacted with nursery planting depth only in the fifth year after planting elms (not maples). Elms shallow in nursery containers required less bending stress to tilt trunks, but only to five degrees (not to lesser angles), than those planted deeply, but only when root balls were not covered with mulch (data not shown).

Bending stress to winch maple trunks to various angles under tension, and trunk rest angle after releasing cable, were not impacted by any factor tested three years after landscape planting (data not shown). Bending stress to five degrees (but not to lesser tilts) increased approximately $15 \%$ by presence of mulch on root ball by four (not shown) and five years after planting (Table 5). Root remediation at planting had no effect on tilting maples one or two degrees (two degrees shown) at four years after planting, but reduced (by about 15\%) bending stress required to tilt trunks three or more degrees (five degrees shown) only when maples were planted deeply in the nursery containers (Table 6). Maples planted shallowly in nursery containers and remediated at planting required more bend-

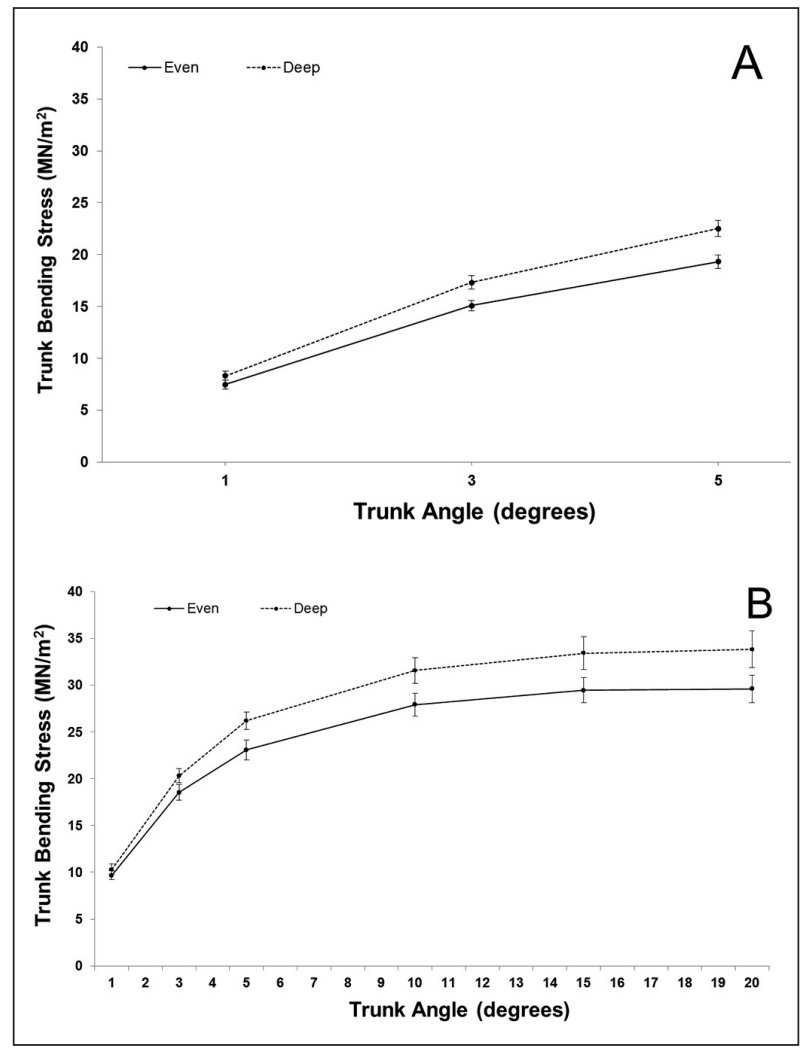

Figure 2. Trunk bending stress three years $(A)$ and five years (B) after landscape planting for elms planted even and deep in nursery containers; vertical bars indicate SE. No interactions were significant $(P>0.05)$; vertical bars indicate SE. Shallow = topmost root $13 \mathrm{~mm}$ deep into $11.4 \mathrm{~L}(\# 3)$ and even with substrate surface into $57 \mathrm{~L}$ (\#15) and $170 \mathrm{~L}$ (\#45) container; deep = topmost root $64 \mathrm{~mm}$ deep into $11.4 \mathrm{~L}$ and $57 \mathrm{~L}$ containers (128 mm deep total), and even into $170 \mathrm{~L}$ container. 


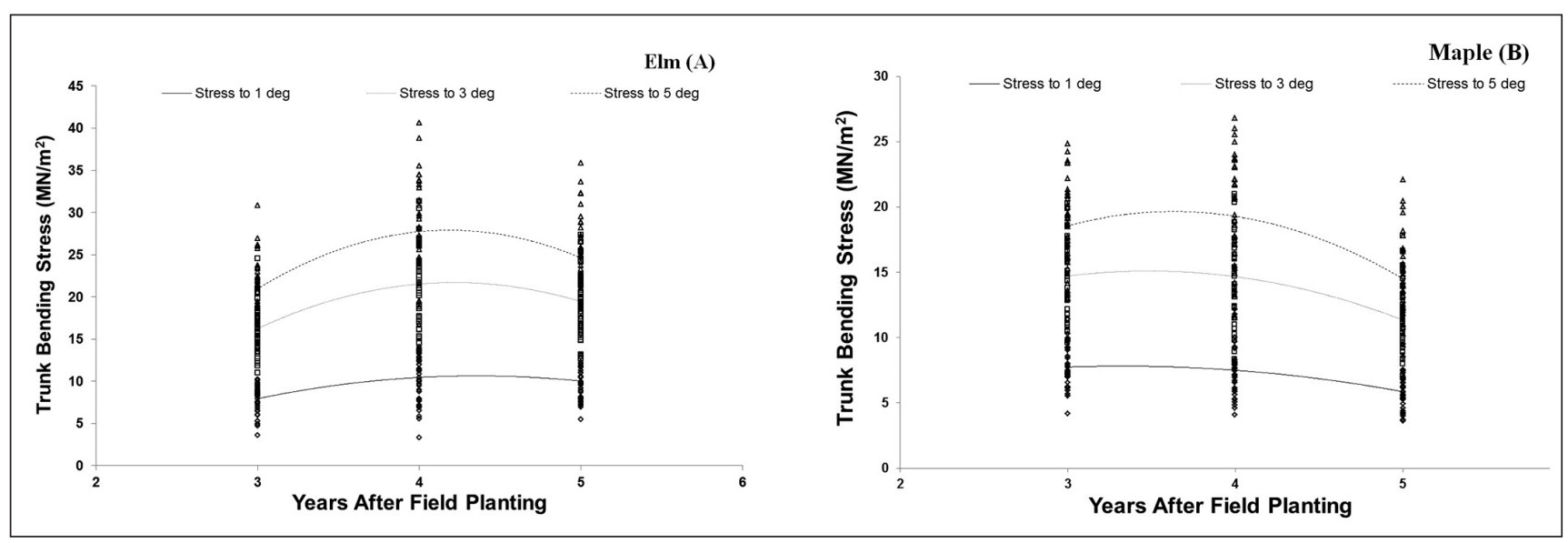

Figure 3. Bending stress required to winch trunks to increasing angles three (2011) to five (2013) years after landscape planting averaged across mulch, planting depth, and root remediation; $n=40$ for each taxa.

For elm (A):

Stress to 1 degree $=12.8$ (year $)-1.5\left(\right.$ year $\left.^{2}\right)-17.3 ; P<0.0001, R^{2}=0.18$.

Stress to 3 degrees $=31.3$ (year) $-3.7\left(\right.$ year $\left.^{2}\right)-44.3 ; P<0.0001, R^{2}=0.25$.

Stress to 5 degrees $=41.4($ year $)-4.9\left(\right.$ year $\left.^{2}\right)-58.7 ; P<0.0001, R^{2}=0.27$.

For maple (B):

Stress to 1 degree $=4.7$ (year) $-0.7\left(\right.$ year $\left.^{2}\right)+0.06 ; P<0.0001, R^{2}=0.22$.

Stress to 3 degrees $=11.4$ (year) $-1.6\left(\right.$ year $\left.^{2}\right)-4.7 ; P<0.0001, R^{2}=0.24$.

Stress to 5 degrees $=20.0($ year $)-2.8\left(\right.$ year $\left.^{2}\right)-16.7 ; P<0.0001, R^{2}=0.27$.

Table 5. Effect of mulch application over the root ball on bending stress to tilt elm and maple trunks five years ${ }^{2}$ after planting in the landscape.

\begin{tabular}{|c|c|c|c|}
\hline $\begin{array}{l}\text { Mulch } 7 \mathrm{~cm} \text { deep } \\
\text { over root ball }\end{array}$ & $\begin{array}{l}\text { Bending stress to } 5 \text { degrees } \\
\text { trunk tilt } 5 \text { years after planting } \\
\left(\mathrm{MN} / \mathrm{m}^{2}\right)\end{array}$ & $\begin{array}{l}\qquad \text { Elm } \\
\text { Bending stress to } 10 \text { degrees trunk } \\
\text { tilt } 5 \text { years after planting } \\
\left(\mathrm{MN} / \mathrm{m}^{2}\right)\end{array}$ & $\begin{array}{l}\text { Bending stress to } 15 \text { degrees trunk tilt } \\
5 \text { years after planting } \\
\left(\mathrm{MN} / \mathrm{m}^{2}\right)\end{array}$ \\
\hline Yes & $25.9 \mathrm{a}^{\mathrm{y}}$ & $31.6 \mathrm{a}$ & $33.4 \mathrm{a}$ \\
\hline \multirow[t]{2}{*}{ No } & $23.3 \mathrm{~b}$ & $27.9 \mathrm{~b}$ & $29.5 \mathrm{~b}$ \\
\hline & & Maple & \\
\hline $\begin{array}{l}\text { Mulch } 7 \mathrm{~cm} \text { deep } \\
\text { over root ball }\end{array}$ & $\begin{array}{l}\text { Bending stress to } 5 \text { degrees trunk tilt } \\
5 \text { years after planting }\left(\mathrm{MN} / \mathrm{m}^{2}\right)\end{array}$ & & \\
\hline Yes & $15.5 \mathrm{a}$ & & \\
\hline No & $13.4 \mathrm{~b}$ & & \\
\hline
\end{tabular}

ing stress to tilt trunks two degrees than those planted deeply (Table 6), but not when winched to more than two degrees at four years after planting (five degrees shown). Despite this interaction in year four, remediation did not impact bending stress and did not interact with planting depth at three and five years after planting.

Bending stress required to tilt trunks increased between three and four years after planting elm and then remained the same (at lowest stress) or decreased (at highest stress) the fifth year (Figure 3).
Stress to tilt maple trunks mostly decreased with time. Bending stress required to tilt elms to various angles in year five was most correlated with CSA associated with leeward and straight roots; stress to tilt maples was most correlated with CSA associated with windward and straight roots (Table 7).

\section{DISCUSSION}

Responses associated with application of a $7 \mathrm{~cm}$ thick (before settling) mulch layer to the root ball surface, compared to a mulch-free root ball, 
Table 6. Effect of nursery planting depth and root remediation at planting on bending stress required to winch maple to various trunk tilts four yearsy $^{y}$ after planting in the landscape.

\begin{tabular}{llll}
\hline $\begin{array}{l}\text { Nursery planting } \\
\text { depth }\end{array}$ & $\begin{array}{l}\text { Root remediation } \\
\text { at planting }\end{array}$ & $\begin{array}{l}\text { Bending stress to two degrees } \\
\text { trunk tilt }\left(\mathrm{MN} / \mathrm{m}^{2}\right)\end{array}$ & $\begin{array}{l}\text { Bending stress to } 5 \text { degrees } \\
\text { trunk tilt }\left(\mathrm{MN} / \mathrm{m}^{2}\right)\end{array}$ \\
\hline Shallow & Yes & $12.4 \mathrm{a}^{\mathrm{w}}$ & $20.1 \mathrm{ab}$ \\
& No & $11.6 \mathrm{ab}$ & $19.0 \mathrm{ab}$ \\
Deep & Yes & $10.3 \mathrm{~b}$ & $17.7 \mathrm{~b}$ \\
& No & $12.2 \mathrm{ab}$ & $20.8 \mathrm{a}$ \\
\hline
\end{tabular}

${ }^{\mathrm{z}}$ Depth $\times$ remediation interaction was insignificant $(P=0.11)$ for tilting to one degree; mean separation for three and four degrees tilt was identical to five degrees.

$\mathrm{y}$ There was no impact three and five years after planting.

${ }^{x}$ Shallow = topmost root $13 \mathrm{~mm}$ deep into $11.4 \mathrm{~L}$ (\#3) and even with substrate surface into $57 \mathrm{~L}$ (\#15) and 170 L (\#45) container; deep = topmost root $64 \mathrm{~mm}$ deep into 11.4 and $57 \mathrm{~L}$ containers (128 $\mathrm{mm}$ deep total), and even into $170 \mathrm{~L}$ container.

${ }^{w}$ Means followed by a different letter within columns are statistically different at $P<0.05, \mathrm{n}=10$, averaged over mulch treatment because three-way interaction with mulch was not significant $(P>0.07)$.

Table 7. Pearson Correlation Coefficients of root attributes (measured $10 \mathrm{~cm}$ beyond planted $170 \mathrm{~L}$ container root ball) with rest angle and bending stress to tilt trunk 5 and 20 degrees five years after planting.

\begin{tabular}{|c|c|c|c|}
\hline \multicolumn{4}{|c|}{ Elm } \\
\hline Root Attribute & Trunk rest angle $\mathrm{z}^{\mathrm{z}}$ & $\begin{array}{l}\text { Trunk bending stress } \\
5 \text { degrees }\end{array}$ & $\begin{array}{l}\text { Trunk bending stress } \\
20 \text { degrees }\end{array}$ \\
\hline CSA leeward ${ }^{y}$ & -0.49 & 0.50 & 0.54 \\
\hline Straight $^{\mathrm{x}}$ CSA leeward ${ }^{\mathrm{y}}$ & -0.37 & 0.48 & 0.51 \\
\hline Ascending ${ }^{\mathrm{w}}$ CSA leeward ${ }^{\mathrm{y}}$ & -0.48 & 0.40 & 0.57 \\
\hline Straight-root ${ }^{\mathrm{x}}$ descending $^{\mathrm{u}}$ CSA & $\mathrm{NS}^{\mathrm{s}}$ & 0.39 & 0.41 \\
\hline Straight-root ${ }^{\mathrm{x}} \mathrm{CSA}$ & -0.40 & 0.33 & 0.40 \\
\hline CSA & -0.45 & 0.33 & 0.41 \\
\hline Ascending ${ }^{\mathrm{w}}$ CSA & -0.61 & NS & 0.45 \\
\hline \multicolumn{4}{|c|}{ Maple } \\
\hline Depth straight ${ }^{x}$ roots windward ${ }^{v}$ & NS & 0.49 & NS \\
\hline Downward ${ }^{\mathrm{t}}$ CSA windward ${ }^{\mathrm{v}}$ & 0.40 & 0.47 & NS \\
\hline Depth straight-roots ${ }^{\mathrm{x}}$ & NS & 0.43 & NS \\
\hline Descending $^{\mathrm{u}}$ CSA windward ${ }^{\mathrm{v}}$ & 0.40 & 0.42 & NS \\
\hline Straight-root ${ }^{\mathrm{x}}$ CSA windward ${ }^{\mathrm{v}}$ & NS & 0.41 & NS \\
\hline CSA windward ${ }^{v}$ & 0.38 & 0.37 & NS \\
\hline Depth & NS & 0.37 & NS \\
\hline Straight-root ${ }^{\mathrm{x}} \mathrm{CSA}$ & NS & 0.36 & NS \\
\hline CSA & NS & 0.34 & NS \\
\hline
\end{tabular}

${ }^{\mathrm{z}}$ Rest angle $=$ trunk angle after releasing pulling cable following winching to 20 degrees trunk tilt.

y Growing in the quadrant toward the pulling winch.

${ }^{x}$ Straight $=$ root segment just beyond the root ball oriented $<60$ degrees in either compass direction compared to azimuth of parent root inside root ball.

${ }^{\mathrm{w}}$ Ascending = growing up toward landscape soil surface.

${ }^{v}$ Windward = growing in the quadrant opposite the pulling winch.

u Descending = growing down $<45$ degrees in relation to landscape soil surface.

${ }^{\mathrm{t}}$ Downward $=$ growing down $>45$ degrees in relation to landscape soil surface.

${ }^{s} P>0.05$.

included 1) less elm trunk diameter growth (Figure 1) during the first two years after planting, 2) a $55 \%$ decrease in elm root CSA (14 versus 26 $\mathrm{cm}^{2}$ ) measured just outside original $170 \mathrm{~L}$ root ball, 3) increased maple root circling near the trunk $(25 \%$ versus $7 \%$ circumference circled, Table 3), and 4) greater maple trunk bark death (52\% versus $19 \%$ trunk circumference dead, Table 4) following root remediation. Others demonstrated reduced survival with mulch on the root ball surface in various climates; the proposed mechanism for damage is water retention in the mulch layer, reducing the amount reaching roots inside the root ball (Gilman and Grabosky 2004; Singer and Martin 2009; Arnold et al. 2010). Mulch also had a negligible impact on evaporation from the root ball surface in climates where irrigation was practically essential to establishing shade trees, especially in the months immediately after planting (Altland and Lanthier 2007; Gilman et al. 2012). Mulch effect may be influenced by its depth (Gilman and Grabosky 2004).

Placing mulch on the root ball increased anchorage about $10 \%$ (elm) to $14 \%$ (maple) at five (but not three and four) years after planting (Table 5). Perhaps slightly better anchorage in the fifth year-and 
only when tilting trunks to certain angles-was due to roots growing up into mulch following root remediation (shown by the threefold increase in percent trunk circled with roots under the mulch, Table 3 ). Watson and Clark (1993) also showed that girdling roots re-formed following root remediation on Acer platanoides L. and can grow into about the same position prior to remediation. Root growth up into soil and mulch over the root collar of trees transplanted from a field nursery has been attributed to deep landscape planting (Wells et al. 2006), or not (Watson et al. 1990). New roots grew over the root collar in the current study only when trees were root remediated at planting, suggesting that mulch should be withheld from root ball on certain trees receiving root remediation. The slight increase in anchorage from mulch application would have to be balanced against potential health problems of roots growing over the collar of certain species; documented health problems can include tree death (Wells et al. 2006).

Few have studied effects of planting depth at onset of container production on growth in the landscape. Like red maple and Chinese elm in the current study, Byran et al. (2010) showed no reduction in trunk diameter growth one year after landscape planting at-grade Chinese elm that were $10 \mathrm{~cm}$ deep in $36 \mathrm{~L}$ containers; neither did Harris and Day (2010) three years after landscape planting at-grade two taxa that were $10 \mathrm{~cm}$ deep in 50 L containers. Elms (not maples) planted deeply in containers in the current study were somewhat better anchored three to five years after planting (Figure 2); however, the significant but slight increase in anchorage is probably outweighed by the negatives. Placing the root collar more than a few mm below the surface encourages roots to grow over the collar of various Quercus, Ulmus, and Acer (Fare 2005; Gilman and Harchick 2008; Bryan et al. 2010; Gilman et al. 2010b) and perhaps other taxa not yet tested. These are considered a source of stem-girdling roots and future health problems (Wells et al. 2006), thus Johnson et al. (2008) recommend removing these at planting. The current study (Table 2) supports this by showing $>55 \%$ of the trunk was circled with roots ( $>5 \mathrm{~mm}$ diameter) at landscape planting and without root remediation five years after planting maple and elm that were deep in their container. This percentage was substantially reduced for both taxa by either planting trees that were grown shallow in their con- tainer, or by root remediation at planting to remove roots over the collar. Planting maples (not elms) that were grown shallow also resulted in smaller $(\mathrm{CSA}=$ $5 \mathrm{~cm}^{2}$ ) roots circling the trunk than maples planted deeper in the substrate $\left(15 \mathrm{~cm}^{2}\right)$, provided they were root remediated (Table 2). Harris and Day (2010) showed, in photographs, roots growing over the root collar, whether remediated or not, but did not quantify differences. There was some evidence that maples planted shallowly and root remediated were slightly better anchored to landscape soil-but only four years after planting - compared to other combinations of planting depth and remediation (Table 6).

Root remediation appeared to improve root systems without influencing post-planting xylem potential, trunk diameter, tree height, or anchorage. No damage to the root collar or surface roots of the flare was apparent on either taxa. Harris and Day (2010) also showed no reduction in trunk diameter growth from root remediation unless root collar was $20 \mathrm{~cm}$ deep in containers. However, root remediation requires a great deal of time by trained individuals (Table 1; Tate 1980) and is likely to be considered cost prohibitive in many circumstances. The benefits to health could be weighed against the costs of inheriting dead or declined trees. There is some evidence that root remediation at planting caused trunk bark death in maples (not elms) within the first 15 months after planting when mulch was placed on the root ball or when planting trees with the root collar deep in the substrate (Table 4). This could become a health issue later.

Root remediation did not impact the diameter of the largest circling root on either taxa, indicating that perhaps root remediation was not conducted deep enough in the root ball to remove the largest circling roots. The largest roots on most trees appeared to be growing down at a considerable angle. Some of the largest roots on trees grown for this study were deflected by the 10,57 , and/or $170 \mathrm{~L}$ container walls (Gilman et al. 2010b); these were probably not cut during root remediation because they were below correction level. Roots growing over the root collar were removed along with surface roots deflected by the \#3, \#15, and \#45 container walls; the slightly deeper large deflected roots were difficult to access and cut in the deeply planted treatment which probably explains the threefold increase in CSA of the largest circling root 
compared to trees planted shallowly (Table 2). The difficulty and time-consuming nature of corrective measures (root remediation) on deeply planted container-grown trees suggests that it is vital for growers to produce root systems with straight roots and the root collar close to the substrate surface.

The impact on anchorage from the factors of mulch placement, root remediation, and nursery planting depth interacted with each other, and varied with year after planting, making broad single-factor interpretation impractical. However, no combination of factors (interactions) resulted in more than a $15 \%$ change in bending stress within an evaluated year (i.e., 3, 4, and 5 years after planting). Bending stress required to tilt trunks to various angles was most correlated with CSA associated with leeward and straight roots (elms) or windward and straight roots (maples, Table 7). Greater resistance to trunk tilting (bending stress) on trees planted from landscape-sized containers has been associated with an abundance of CSA in windward roots on Quercus virginiana (Gilman and Wiese 2012), and largediameter straight roots on Acer rubrum (Gilman et al. 2013) and Sweitenia mahogani L. (Gilman et al. 2014). Amount of deflected roots has also been associated with poor anchorage (Gilman and Wiese 2012; Gilman et al. 2013). The initial increase with time followed by a drop in bending stress required to tilt elm and maple trunks (Figure 3) suggests that trees could be more susceptible to tilting and perhaps uprooting in a storm as they became established beyond three or four years. It is not clear if this trend would continue beyond the fifth year after planting or how this might apply to other species.

In conclusion, trees of both taxa planted deeply in the nursery root ball had a greater amount and severity of circling roots when planted into the landscape (Gilman et al. 2010b) and five years later (current study) compared to those planted shallowly in the nursery container. Circling roots present at the time of planting persisted five growing seasons after landscape planting (Table 2), and new adventitious roots did not grow from the base of the trunk of either taxa. Circling root severity depended on root remediation at planting. Circling and other deflected roots were substantially pruned away at planting, which resulted in straighter roots, without impacting physiological stress (stem xylem potential), growth rate, or anchorage up to five growing seasons after planting. By con- trast, Watson and Clark (1993) found that new roots growing from the pruning cuts on remediated trees planted four to ten years earlier typically grew back into a position to girdle the trunk once again three years later. It was not clear, unlike the current study, if an effort was made in that study to cut roots in a manner that resulted in the face of the cut away from the trunk. Like Tate (1980) and Watson and Clark (1993) found, remediation was extremely time-consuming - up to three hours per tree-on Acer platanoides. Roots that occasionally grow over the root collar in natural forest systems are typically from nearby trees-not the tree being evaluated-and have not been associated with decline in health (Lyford and Wilson 1964). The abundance of roots in this position in nursery containers, caused by deflection from the container wall and/or deep planting, appears to increase the likelihood of one or more becoming large. This can cause instability (Gilman and Masters 2010), trunk injury (Table 4), and symptoms associated with chronic stress (Arnold et al. 2007). However, many trees with deformed root systems in the nursery and landscape appear to grow without stress symptoms (Byran et al. 2010; Harris and Day 2010; current study), indicating there is still more to learn about what constitutes a deformed root system. For now, following strategies that result in straight structural roots radiating from the trunk appear to be reasonable, and there are methods of producing trees with this morphology (e.g., Gilman and Paz 2014).

All studies to date, including the current one, were conducted on trees that met current nursery standards for size (Anonymous 2004), and they show that roots deformed in nursery roots balls can persist for many years after landscape planting. Research should focus on trees larger than standard size because so many are planted, especially in slow markets (pers. obs.). Longer-term studies are also needed because some problems appear to manifest only decades after planting (Tate 1980). There appears to be agreement (Byran et al 2010; Harris and Day 2010; current study) that the root collar in nursery containers should be close to the substrate surface. Mulch placed over the root ball at planting did not improve growth or health on either taxa, and appeared to hinder trunk diameter growth on elms, which was demonstrated on other taxa in various climates (Arnold 2005; Singer and Martin 2009). Withholding mulch from the root ball surface dramatically reduced roots circling 
maple trunks following root remediation. Other taxa may respond differently than shown in this study.

Acknowledgments. Thanks to Marshall Tree Farm, Moriston, Florida, U.S., for supplying the tree spade used to harvest root balls.

\section{LITERATURE CITED}

Altland, J., and M. Lanthier. 2007. Influence of container mulches on irrigation and nutrient management. Journal of Environmental Horticulture 25:234-238.

Anonymous. 1998. Florida grades and standards for nursery plants. Florida Department of Agriculture and Consumer Services, Tallahassee, Florida, U.S.

Anonymous. 2004. American Standard for Nursery Stock. Z60. American Nursery and Landscape Association, Washington, D.C.

Arnold, M.A. 2005. Planting depth and mulch thickness affect establishment of green ash (Fraxinus pennsylvanica) and Bougainvillea goldenraintree (Koelreuteria bipinnata). Journal of Arboriculture 31:163-170.

Arnold, M.A., and G.V. McDonald. 2009. Groundcovers, organic and inorganic mulches, and masonry surfaces differentially affect establishment and root zone characteristics of urban trees. Arboriculture \& Urban Forestry 35:232-240.

Arnold, M.A., G.V. McDonald, D.L. Bryan, G.C. Denny, W.T. Watson, and L. Lombardini. 2007. Belowgrade planting adversely affects survival and growth of tree species from five different families. Arboriculture \& Urban Forestry 33:64-69.

Browne, C., and K. Tilt. 1992. Effects of planting depth on three ornamental trees. Proceedings Southern Nurseryman Association $37: 2-4$

Bryan D.L., M.A. Arnold, A. Volder, W.T. Watson, L. Lombardi, J.J. Sloan. L.A. Valdez-Aguilar, and A.D. Cartmill. 2010. Planting depth during container production and landscape establishment affects growth of lacebark elm. HortScience 45:54-60.

Bryan, D.L., M.A. Arnold, A. Volder, W.T. Watson, L. Lombardi, J.J. Sloan, and A.D. Cartmill. 2008. Overview of selected studies on the influence of planting depth on landscape establishment on container-grown trees. In: The Landscape Below Ground III. G.W. Watson, L. Costello, B. Scharenbroch, and E.F. Gilman (Eds.). Proceedings of International Workshop on Tree Root Development in Urban Soils. Morton Arboretum, Lisle, IL: International Society of Arboriculture, Champaign Illinois, U.S.

Downer, J., and D. Hodel. 2001. The effects of mulching on establishment of Syagrus romanzoffiana (Cham.) Becc., Washingtonia robusta (H. Wendl.), and Archontophoenix cunninghamiana (H. Wendl.) H. Wendl. \& Drude in the landscape. Scientia Horticulturae 87:85-92.

Fare, D. 2005. Should potting depth be a concern for container trees? In: G. Watson and A. Hewitt (Eds.). Trees and planting: Getting the roots right conference proceedings. Morton Arboretum, Lisle, Illinois, U.S.

Ferrini, F., A. Fini, G. Amoroso, and P. Frangi. 2008. Mulching of ornamental trees: Effects on growth and physiology. Arboriculture \& Urban Forestry 34:157-162.

Gilman, E.F. 2013. Anchorage influenced by production method and root pruning. Arboriculture \& Urban Forestry 39:1-5.

Gilman, E.F., and C. Harchick. 2008. Planting depth in containers affects root form and tree quality. Journal of Environmental Horticulture 26:129-134.
Gilman, E.F., and C. Wiese. 2012. Root pruning at planting and planting depth in the nursery impact root system morphology and anchorage. Arboriculture \& Urban Forestry 38:229-236.

Gilman, E.F., and F. Masters. 2010. Effect of tree size, root pruning and production method on root growth and lateral stability of Quercus virginiana. Arboriculture \& Urban Forestry 36:281-291.

Gilman, E.F., and J.C. Grabosky. 2004. Mulch and planting depth affect live oak (Quercus virginiana Mill.). Journal of Arboriculture 30:311-317.

Gilman, E.F., and J.C. Grabosky. 2011. Quercus virginiana root attributes and lateral stability after planting at different depths. Urban Forestry \& Urban Greening 10:3-9.

Gilman, E.F., and M. Paz. 2014. Root system morphology influenced by container design, retention time, and root pruning. Arboriculture \& Urban Forestry 40:16-25.

Gilman, E.F., C. Harchick, and C. Wiese. 2009. Pruning roots affects tree quality in container-grown oaks. Journal of Environmental Horticulture 27:7-11.

Gilman, E.F., C. Harchick, and M. Paz. 2010a. Effect of container type on root form and growth of red maple. Journal of Environmental Horticulture 28:1-7.

Gilman, E.F., C. Harchick, and M. Paz. 2010b. Planting depth affects root form of three shade tree cultivars in containers. Arboriculture \& Urban Forestry 36:132-139.

Gilman, E.F., J. Miesbauer, C. Harchick, and R.C. Beeson. 2013. Impact of tree size at planting, mulch and irrigation on Acer rubrum L. growth and anchorage. Arboriculture \& Urban Forestry 39:173-181.

Gilman, E.F., M. Paz, and C. Harchick. 2010c. Root ball shaving improves root systems on seven tree species in containers. Journal of Environmental Horticulture 28:13-18.

Gilman, E.F., R.C. Beeson, and D. Meador. 2012. Impact of mulch on water loss from a container substrate and native soil. Arboriculture \& Urban Forestry 38:18-23.

Harris, J.R., and S. Day. 2010. Planting depth at onset of container production and subsequent root ball remediation at transplanting of pin oak and linden. HortScience 45:1793-1797.

Harris, R.W., W.B. Davis, N.W. Stice, and D. Long. 1971a. Influence of transplanting time in nursery production. Journal American Society Horticulture Science 96:109-110.

Harris, R.W., W.B. Davis, N.W. Stice, and D. Long. 1971b. Root pruning improves nursery tree quality. Journal American Society Horticulture Science 96:105-108.

Hensley, D.L., R.E. McNiel, and R. Sundheim. 1988. Management influences on growth of transplanted Magnolia grandiflora. Journal of Arboriculture 14:204-207.

Hild, A.L., and D.L. Morgan. 1993. Mulch effects on crown growth of five southwestern shrub species. Journal of Environmental Horticulture 11:41-43.

Johnson, J.R., G.R. Johnson, M.H. McDonough, L. Burban, and J.K. Monear. 2008. Tree owner's manual. NE Area State and Private Forestry USDA Forest Service, Newtown Square, Pennsylvania, U.S.

Kraus, H.T. 1998. Effects of mulch on soil moisture and growth of desert willow. HortTechnology 8:588-590.

Litzow, M., and H. Pellet. 1983. Influence of mulch materials on growth of green ash. Journal of Arboriculture 9:7-12.

Lyford, W.H., and B.F. Wilson. 1964. Development of the root system of Acer rubrum L. Harvard Forest Paper No. 10. 
Montague, T., C. McKenney, M. Maurer, and B. Winn. 2007. Influence of irrigation volume and mulch on establishment of select shrubs species. Arboriculture \& Urban Forestry 33:202-209.

Scharenbroch, B. 2009. A meta-analysis of studies published in Arboriculture \& Urban Forestry relating to organic materials and impacts on soil, tree, and environmental properties. Arboriculture \& Urban Forestry 35:221-231.

Singer, C.K., and C.A. Martin. 2009. Effect of landscape mulches and drip irrigation on transplant establishment and growth of three North American desert native plants. Journal of Environmental Horticulture 27:166-170.

Smith, M.W., B.K. Carroll, and B.S. Cheary. 2000. Mulch improves pecan tree growth during orchard establishment. HortScience 35:192-195.

Tate, R.L. 1980. Detection, description and treatment of girdling roots on urban Norway maple trees. Ph.D. Thesis, University of Michigan.

Watson, G.W., and S. Clark. 1993. Regeneration of girdling roots after removal. Journal of Arboriculture 19:278-280.

Watson, G.W., S. Clark, and K. Johnson. 1990. Formation of girdling roots. Journal of Arboriculture 16:197-202.

Wells, C., C.E.K.S. Townsend, J.D. Caldwell, D.L. Ham, M. Sherwood, and E.T. Smiley. 2006. Effects of planting depth on landscape tree survival and girdling root formation. Arboriculture \& Urban Forestry 32:305-311.

\section{Edward F. Gilman (corresponding author) \\ University of Florida \\ Environmental Horticulture \\ 1533 Fifield Hall \\ Gainesville, Florida 32611, U.S.}

\author{
Maria Paz \\ University of Florida \\ Environmental Horticulture \\ 1533 Fifield Hall \\ Gainesville, Florida 32611, U.S.
}

\section{Chris Harchick \\ University of Florida \\ Environmental Horticulture \\ 1533 Fifield Hall \\ Gainesville, Florida 32611, U.S.}

Résumé. L'influence de la profondeur du collet racinaire d'un arbre en motte produit en pépinière et le potentiel de croissance racinaire lors de sa plantation subséquente font l'objet de recherches croissantes. L'application de paillis autour du tronc suite à la plantation a également récemment été remise en question. Les arbres plantés plus profondément dans des contenants en pépinière requéraient $41 \%$ plus de temps pour enlever le substrat superflu et les racines s'étant développées au-dessus du collet par rapport aux arbres plantés moins profondément dans les contenants. Les racines encerclantes d'arbres plantés provenant de contenants de 170 L étaient encore présentes jusqu'à cinq saisons de croissance après la plantation à moins qu'elles n'aient été élaguées dès la plantation. L'élagage des racines problématiques lors de la plantation a amélioré le développement du système racinaire chez les ormes Ulmus et les érables Acer, et a considérablement réduit le pourcentage de racines encerclantes sans pour autant avoir un impact sur le potentiel de croissance du xylème, la croissance du houppier, ou l'ancrage au sol durant les cinq premières années suivant leur plantation. Le paillis appliqué autour du tronc à la plantation a généré davantage de repousses de racines encerclantes chez les Acer mais pas chez les Ulmus et ce, malgré l'élagage des racines problématiques au moment de la plantation. Il s'est avéré plus facile deétablir une corrélation entre la contrainte de flexion pour déstabiliser la motte et faire incliner les troncs en considérant la surface terrière des racines rectilignes situées sous-le-vent chez les Ulmus ou celle des racines rectilignes situées face au vent sur les Acer. L'augmentation initiale de la durée requise en contrainte de stress pour faire incliner les troncs après la plantation suivi d'une diminution de la contrainte de stress par la suite, suggère que les arbres plantés produits en contenants seraient plus susceptibles au déracinement lors de vents violents pendant les trois ou quatre années suivant la plantation.

Zusammenfassung. Der Einfluss der Wurzelhalstiefe in Baumschulwurzelballen und potentieller Wurzelsanierung bei der Auspflanzung in die Landschaft ist in zunehmendem Maß ein Ziel der Forschung. Der Einsatz von Mulch auf den Wurzelballen ist ebenso gegenwärtig von Interesse. Bäume, welche tief in die Pflanzcontainer gepflanzt wurden, erforderten mehr als $41 \%$ mehr Zeit, um Substrat und Wurzeln oberhalb des Wurzelhalses zu entfernen, als flach gepflanzte Bäume. Würgewurzeln an Bäumen aus 1701 Containern blieben für fünf Wachstumsperioden bestehen, es sei denn, sie wurden beim Pflanzen zurück geschnitten. Eine Wurzelsanierung verbesserte die Wurzelsysteme von Ulmus und Acer erheblich, indem der Anteil des umschlungenen Stammes ohne Beeinflussung des Xylem-Potentials nach der Pflanzung, das Kronenwachstum oder die Verankerung in den ersten fünf Jahren nach der Pflanzung reduziert wurde. Mulch auf dem Wurzelballen verursachte bei Acer mehr Würgewurzeln als bei Ulmus, gefolgt von Wurzelsanierung. Der Biegestress beim Bewegen des Stammes war sehr korreliert mit der Querschnittsfläche der windabseits gelegenen und geraden Wurzeln bei Ulmus oder den windwärts gerichteten geraden Wurzeln bei Acer. Der erste Anstieg des erforderlichen Biegemoments, um den Stamm nach dem Verpflanzen zu bewegen, gefolgt von einem Abfall des Biegesstresses verdeutlicht, dass verpflanzte Bäume aus Baumschulcontainern etwas mehr abfällig sind, bei Sturmereignissen entwurzelt zu werden, während sie nach drei bis vier Jahren standortetabliert sind.

Resumen. La influencia de la profundidad de cuello de la raíz en la bola del cepellón en el vivero y la remediación potencial al momento de plantar en el paisaje, son objeto de investigación. La colocación del mantillo en la superficie del cepellón al momento de la plantación también se ha puesto en duda recientemente. Los árboles plantados profundamente en contenedores de vivero requieren $\geq 41$ por ciento más de tiempo para eliminar el sustrato y las raíces que han crecido por encima del cuello de la raíz que los árboles plantados superficialmente. Las raíces enrolladoras en los árboles plantados en contenedores de $170 \mathrm{~L}$ persistieron durante cinco estaciones de crecimiento después de la plantación en el paisaje, a menos que se podaran durante la plantación. La remediación de raíz mejoró los sistemas de raíces de Ulmus y Acer reduciendo drásticamente el porciento de tronco con raíces enrolladas sin influir en el xilema potencial post-plantación, el crecimiento de la copa, o anclaje durante los primeros cinco años después de la plantación en el paisaje. El mantillo colocado en la superficie de la bola de la raíz causó más crecimiento de raíces circulares sobre Acer pero no en Ulmus-después de la remediación de la raíz. El esfuerzo de flexión para inclinar troncos estuvo más correlacionado con el área de sección transversal del lado de sotavento y raíces verticales en Ulmus o de barlovento y raíces verticales en Acer. El aumento inicial con el tiempo en tensión requerida para inclinar troncos después de la plantación, seguido por una caída de tensión de flexión, sugiere que los árboles plantados de contenedores de vivero podrían ser más susceptibles a salirse en una tormenta de viento, ya que se establecieron más allá de tres o cuatro años. 